\title{
MEMBANGUN KOMUNIKASI INTERPERSONAL ORANG TUA DENGAN ANAK DALAM KELUARGA
}

\author{
Fabianus Fensi \\ Universitas Bunda Mulia \\ Email: fabianusfensi@gmail.com
}

\begin{abstract}
The communication model in the family is part of the interpersonal communication. Here the role of parents can be called as the main communicator in the delivery of communication messages. To achieve the effectiveness of a parent communication certainly has its own way of delivering messages to their children, especially when children face certain problems in their social life. As an effective message delivery standard, this activity suggests three possible patterns of communication skills, including: listening communication; Open communication; and honest communication. Listening communication is a parent-to-child interpersonal communication model, or a form of communication involved, especially in responding to the psychological needs of the child. Open communication is a communication that enables messengers and message recipients to understand what they want to achieve in an ongoing communication. Parents as messengers and children as recipients of the message occupy the same position in the exchange of communication messages they are building. While honest communication is a communication model that is delivered with the aim of fostering self-esteem of children. These three models of communication, apart from being the most important way to find solutions to problems faced by children, as well as a way to counter the tendency of self-egoism of parents. With these communication patterns parents are able to absorb what children expect. And, in this way, children feel understood and appreciated by their parents.
\end{abstract}

Keywords: Interpersonal Communication, Listening, Open, Honest.

ABSTRAK: Model komunikasi dalam keluarga merupakan bagian dari komunikasi interpersonal. Di sini peran orang tua dapat disebut sebagai komunikator utama dalam penyampaian pesan komunikasi. Untuk mencapai efektivitas sebuah komunikasi orang tua tentu memiliki cara tersendiri menyampaikan pesan kepada anak-anak mereka, terutama ketika anak-anak menghadapi masalah tertentu dalam kehidupan sosial mereka. Sebagai standar penyampaian pesan yang efektif, kegiatan ini menganjurkan tiga pola keterampilan komunikasi yang dimungkinkan, antara lain: komunikasi yang mendengarkan; komunikasi yang terbuka; dan komunikasi yang jujur. Komunikasi yang mendengarkan adalah model komunikasi interpersonal orangtua dengan anak, atau suatu bentuk komunikasi yang terlibat, terutama dalam menjawabi berbagai kebutuhan psikologis anak. Komunikasi yang terbuka adalah komunikasi yang memungkinkan penyampai pesan dan penerima pesan dapat memahami apa yang ingin dicapai dalam sebuah komunikasi yang sedang dijalankan. Orang tua sebagai penyampai pesan dan anak sebagai penerima pesan menduduki posisi yang sama dalam pertukaran pesan komunikasi yang sedang mereka bangun. Sementara komunikasi yang jujur adalah model komunikasi yang disampaikan dengan tujuan menumbuhkan sikap menghargai diri anak. Ketiga model komunikasi ini, selain sebagai cara terpenting untuk menemukan solusi atas masalah yang dihadapi anak, juga sebagai cara untuk melawan kecenderungan egoisme diri orang tua. Dengan pola-pola komunikasi ini orang tua mampu menyerap apa yang diharapkan anak-anak. Dan, dengan cara itu pula anak-anak merasa dimengerti dan dihargai oleh orang tua mereka.

Kata Kunci: Komunikasi Interpersonal, Mendengarkan, Terbuka, Jujur

\section{PENDAHULUAN}

\section{Latar belakang Masalah}

Relasi antara orang tua dan anak dalam keluarga adalah relasi yang dibangun di atas dasar komunikasi. Tidak ada satu pun keluarga di muka bumi ini yang tidak saling berkomunikasi satu sama lain. Bahkan, setiap saat kita berkomunikasi dengan anggota keluarga yang lain. Kita berkomunikasi pada saat makan, berkomunikasi pada saat menonton televisi, kita berkomunikasi pada saat berbelanja di 
mall, kita bahkan berkomunikasi untuk menentukan tempat berwisata, dan lain sebagainya.

Atau, mau dikatakan bahwa begitu seringnya komunikasi dilakukan di rumah. Namun, satu hal yang perlu disadari bahwa sebuah komunikasi efektif tidak saja diukur dari keseringan komunikasi itu dilakukan tetapi juga diukur dari kualitas komunikasi. Banyak sekali kesalahan komunikasi yang dilakukan orang tua terhadap anak-anaknya di rumah. Kesalahan komunikasi itu antara lain: ada kecenderungan memerintah; mengancam anak; menceramahi/menggurui; menginterogasi; mencap/memberi label tertentu (malas, nakal, bandel, lelet, dan lain-lain); membanding-bandingkan; menghakimi; menyalahkan; menyindir; dan membohongi. ${ }^{1}$

Pola komunikasi model seperti ini akan membuat anak menjadi tidak percaya diri; merasa tidak dihargai yang berakibat pada dia sendiri tidak menghargai dirinya; merasa disepelehkan; selalu merasa takut/tidak dilindungi; merasa dijauhkan dari perhatian; dan pada akhirnya anak tidak mampu mengaktualisasikan dirinya di tengah kehidupan sosial bersama temantemannya karena dia bukan yang terbaik di antara mereka.

Pola komunikasi seperti ini disadari atau tidak disadari sering dilakukan orangtua ketika menghadapi anak-anak bermasalah dalam lingkungan sosial mereka. Seharusnya model komunikasi yang dibangun adalah komunikasi yang menumbuhkan rasa percaya diri sehingga kreativitas dan potensi diri anak dapat diaktualkan secara maksimal dalam dunia bermain bersama temantemannya di lingkungan masyarakat maupun di lingkungan sekolahnya.

Permasalahan yang diungkapan inilah yang melatarbelakangi kegiatan ini dilakukan kepada para orang tua, terutama ibu-ibu rumah tangga di RW 018, Kelurahan

${ }^{1}$ Olifia, Hilda. "13 Kesalahan Komunikasi Orang Tua Terhadap Anak Yang Harus Segera Diubah", diakses dari

http://www.rancahpost.co.id/20160251061/13-

kesalahan-komunikasi-orang-tua-terhadap-

anak-yang-harus-segera-diubah/, 18/04/2017, jam 14;24.
Penjagalan, Kecamatan Penjaringan, Jakarta Utara

\section{Identifikasi Masalah}

Komisi Perlindungan Anak Indonesia $(\mathrm{KPAI})^{2}$ mencatat sekurangkurangnya sepuluh masalah yang harus diwaspadai orang tua terjadi pada anak, yaitu: Pertama, obesitas berkaitan dengan asupan kalori yang masuk ke dalam tubuh anak tidak sebanding dengan yang keluar dari tubuhnya. Hal ini terjadi karena pola konsumsi makan cepat saji, kurangnya aktivitas fisik, terlalu banyak melakukan kegiatan duduk (main game, computer, dan menonton televisi.

Kedua, penyalahgunaan obat terlarang atau narkoba pada anak remaja. Efeknya membuat anak menjadi lebih tenang dan melupakan masalah, namun yang terjadi pelupaan yang bersifat semu. Bahaya yang bisa saja terjadi adalah overdosis, efek intoxication (kecelakaan/luka), adiksi/kecanduan, dan efek kesehatan (kerusakan otak dan HIV/AIDS, dan hepatitis).

Ketiga, merokok. Didasari oleh rasa ingin tahu yang besar anak cenderung berusaha mencoba sesuatu yang baru, termasuk di dalamnya mencoba merokok. Tercatat bahwa para perokok dewasa sebagian besar memulai kebiasaan merokok sejak usia anak-anak. Kondisi ini mencemaskan orang tua apalagi kalau mereka mengetahui anaknya sudah mulai merokok.

Keempat, keamanan internet. Internet adalah media di mana anak-anak paling mudah mendapatkan informasi. Namun, perlu diantisipasi keamanan berinternet. Anak-anak bisa saja terjerumus untuk mendapatkan informasi yang salah, seperti: informasi seks yang salah, pornografi, dan

\footnotetext{
${ }^{2}$ Laman KPAI, 5 Juni 2013, http://www.kpai.go.id/tinjauan/10-masalahanak-yang-bikin-orang-tua-ketarketir/11/04/2017, diakses 11/04/2017, jam 16:09.
} 
kekerasan. Semuan informasi yang diterima akan sangat memengaruhi perilaku mereka.

Kelima, kondisi psikologis, seperti stress juga dialami anak-anak. Stres pada anak biasanya berhubungan dengan tugas sekolah yang banyak, lingkungan sekolah yang tidak nyaman, atau merasa tertekan menghadapi ujian. Kondisi ini jarang diungkapkan anak secaara terbuka sehingga menimbulkan perilaku stres pada anak.

Keenam, perilaku kekerasan (bullying). Bullying yang dialami anak-anak bisa saja berasal dari teman-teman sekolah, lingkungan sekitar tempat bermainnya, juga bahkan berasal dari keluarganya. Tercatat anak-anak korban bullying, ditengarai empat belas kali lebih mungkin memiliki masalah perilaku dan emosional mereka. Kekerasan usia dini harus segera dihentikan. Kekerasan pada anak tidak hanya menimbulkan luka fisik, tetapi yang perlu diwaspadai adalah timbulnya luka-luka psikis, seperti pengalaman traumatis, yang cepat atau lambat pasti akan memengaruhi perkembangan mental psikologis seorang anak.

Ketujuh, kehamilan di usia muda. Kehamilan di usia muda menimbulkan risiko besar pada diri seorang anak perempuan. Dari beberapa studi ditemukan bahwa anak perempauan hamil muda berisiko empat kali lipat lebih tinggi mengalami luka parah dan kematian saat melahirkan. Secara fisiologis organ reproduksi dan sel telur anak belum siap untuk mengandung sehingga berisiko mengalami tekanan darah tinggi yang tidak terdeteksi.

Kedelapan, pelecehan dan penelantaran anak. Pelecehan, baik secara seksual maupun fisik, juga penelantaran akan menimbulkan trauma tersendiri bagi anak. Kondisi ini bisa mempengaruhi perkembangan anak baik secara mental maupun fisik. Risiko kesehatan juga bisa timbul terkait dengan strategi coping (penyelesaian masalah) pada korban pelecehan atau penelantaran, seperti makan berlebihan, penggunaan alkohol, dan merokok. Hal berpengaruh besae pada masalah kesehatan anak.

Kesembilan, penyalahgunaan alkohol. Dari sisi aturan, alkohol tidak boleh dijual pada anak dibawah umur. Namun, kenyataannya banyak anak yang pernah mengonsumsi alkohol. Dikhawatirkan, jika sejak kecil anak terbiasa mengonsumsi alkohol, akan memicu kecanduan yang berisiko bagi kesehatannya. Penyalahgunaan alkohol berdampak buruk bagi kesehatan berbagai organ tubuh, seperti i otak, saluran pencernaan (mulut sampai usus besar), hati /liver, pankreas, otot, tulang, dan sistem reproduksi.

Kesepuluh, ketiadaan waktu berolahraga. Orang tua seharus sudah mulai khawatir menyaksikan anak yang lebih banyak nonton televisi atau main game di depan komputer, sehingga tidak memiliki waktu untuk berolahraga. Kondisi ini memicu anak kelebihan berat badan (obesitas) sehingga mudah terkena penyakit.

\section{TUJUAN DAN MANFAAT KEGIATAN Tujuan Kegiatan:}

Memberi pemahaman kepada para orang tua tentang arti pentingnya berkomunikasi dengan anak, terutama ketika anak sudah mulai mengakrabi dunia bermasalah seperti digambarkan dalam identifikasi masalah di atas.

Dunia bermasalah, tentu dalam perspektif orang tua, karena dunia bermasalah ini, tidak jarang selalu diikuti oleh perilaku bermasalah pula. Perilaku bermasalah ini perlu dikomunikasi dengan baik, sehingga anak dapat memahami dengan baik apa yang sedang terjadi dalam hidupnya sehingga kehidupan bersama dalam keluarga pun menjadi lebih baik.

\section{Manfaat Kegiatan:}

Para orangtua memiliki kemampuan praktis untuk memahami masalah-masalah yang dihadapi anak-anak dengan cara mendengarkan mereka. Berbicara secara terbuka dan jujur. Makanya, orang tua mestinya memiliki kemampuan berkomunikasi dengan kurang lebih tiga cara sederhana ini, yaitu dengan cara yang mendengarkan, terbuka, dan jujur sehingga bisa menemukan cara yang tepat untuk mendeteksi dan mengatasi masalah pada anak secara tepat dan empatik. Sering kali terjadi bahwa kesalahan berkomunikasi melahirkan kesalahan orang tua dalam 
melakukan diagnosa terhadap masalah yang sedang dihadapi seorang anak.

\section{TINJAUAN PUSTAKA}

Komunikasi antara orangtua dengan anak dalam lingkup keluarga, termasuk dalam kelompok komunikasi interpersonal. Ada berbagai definisi komunikasi interpersonal. Joseph de Vito, mendefinisikan komunikasi interpersonal sebagai proses pengiriman dan penerimaan pesan di antara dua orang atau lebih formal maupun informal. Komunikasi interpersonal mengharuskan pelaku bertatap muka antara dua orang atau lebih dengan membawa pesan verbal maupun nonverbal sehingga masing-masing bisa memahami satu sama lain dan berinteraksi secara efektif. ${ }^{3}$

Marcolm R. Parks membuat batasan tentang komunikasi interpersonal sebagai komunikasi yang diatur oleh norma relasional. Terjadi pada kelompok yang relatif kecil, seperti keluarga. Norma-norma hubungan dikembangkan dan dipelihara hanya pada hubungan dekat dan akrab. Begitu kelompok menjadi besar komunikasi berkembang menjadi formal dan tidak bersifat pribadi lagi. ${ }^{4}$

Atau, Kathleen S. Verderber mendefinisikan komunikasi interpersonal sebagai proses melalui mana orang menciptakan atau mengelola hubungan mereka, melaksanakan tanggung jawab timbal balik dalam menciptakan makna. ${ }^{5}$ Dengan cara deskriptif, Richard L. Weaver memberi karakteristik khas pada komunikasi interpersonal sebagai berikut: melibatkan paling sedikit dua orang; adanya feedback/kilas balik spontan; tidak harus tatap muka; tidak harus memiliki tujuan tertentu; menghasilkan beberapa efek; tidak harus menggunakan/melibatkan kata-kata; dipengaruhi oleh konteks tertentu; dan dipengaruhi oleh kegaduhan (noise). ${ }^{6}$

${ }^{3}$ De Vito, Joseph. $2009 . \quad$ Komunikasi Antarmanusia. Jakarta: Profesional Books.

${ }^{4}$ Budyatna, Muhammad \& Leila Mona Ganiem. 2012. Teori Komunikasi Antarpribadi. Jakarta: Prenada Media Group, hal. 13

${ }^{5}$ Ibid., hal. 14

${ }^{6}$ Ibid., hal. 15-20
Norma relasional dalam sebuah komunikasi interpersonal ditandai oleh keakraban satu sama lain. Dan keakraban itu sendiri ditandai lima hal penting yaitu: kebersamaan; kesalingbergantungan (satu sama lain memperoleh dukungan, sumber daya, pengertian, tindakan, dan mereka yang terlibat merasa sepakat atas kebergantungan tersebut); rasa percaya; komitmen; dan saling memperhatikan. ${ }^{7}$

Dikatakan di atas bahwa komunikasi interpersonal efektif dilakukan dalam keluarga karena komunikasi dalam keluarga berpola berdasarkan skema tertentu yang sangat menentukan bagaimana anggotanya berkomunikasi. Skema tersebut memusatkan perhatian pada tiga bidang, yaitu: seberapa dekat satu anggota keluarga dengan anggota lainnya; Bagaimana tingkat individualitas dibangun dalam keluarga; dan bagaimana factor eksternal memengaruhi keluarga tersebut. $^{8}$

Sebuah komunikasi interpersonal efektif, tidak saja ditentukan oleh kemampuan berkomunikasi secara verbal, tetapi kalau dalam pelaksanaannya terjadi kombinasi dari seperangkat kemampuan nonverbal, seperti: proses mendengarkan; kemampuan memberi penekanan tertentu pada momen spesial mitra komunikasi; kapasitas untuk menghargai dan memahami siapa saja yang terlibat dalam komunikasi tersebut. $^{9}$

Atau, pakar komunikasi Prof. Dr. Deddy Mulyana, mengatakan bahwa keberhasilan sebuah komunikasi interpersonal menjadi tangggungjawab peserta komunikasi. Kedekatan hubungan pihak yang berkomunikasi akan tercermin pada jenis pesan atau respon nonverbal melalui sentuhan, tatapan mata, dan jarak fisik yang dekat. ${ }^{10}$

\footnotetext{
7 Tubbs, Stewart L - Sylvia Moss. 2005. Human Communication (terjemahan Deddy Mulyana). Bandung: Rosdakarya, hal. 20

${ }^{8}$ Fensi, Fabianus. 2016. "Mendengarkan sebagai Model komunikasi untuk Memahami Remaja" dalam Psibernetika, Vol. 9, No. 2, hal. 147.

9Jo-Ann. 2012. "How to Become an Effective Communicator". Penton Media, Inc. Nov 26.

${ }^{10}$ Mulyana, Deddy. 2015. Komunikasi Suatu

Pengantar. Bandung: Rosdakarya, hal. 18.
} 
Komunikasi interpersonal sangat potensial untuk memengaruhi/membujuk orang lain karena mereka yang terlibat kemungkinan besar menggunakan kelima indera untuk mempertinggi daya bujuk atas pesan yang diterima. ${ }^{11}$

\section{METODE}

Kegiatan pengabdian masyarakat ini dilakukan dengan metode penyuluhan dan diskusi bersama. Para orang tua, terutama, ibu-ibu di RW 018, Kelurahan Penjagalan, Kecamatan Penjaringan, Jakarta Utara dikumpulkan kemudian diajak untuk berdiskusi tentang dua pertanyaan berikut:

- Apa saja yang biasa dilakukan orang tua ketika anak-anak menghadapi masalah, seperti: penyalahgunaan obat terlarang atau narkoba, merokok, kecanduan internet, stres, terlibat dalam tindak kekerasan, pelecehan seksual, dan penyalahgunaan alkohol?

- Bagaimana cara orangtua mengkomunikasikan tindakan pemecahan masalah yang dihadapi anak sehingga mereka tidak terluka?

Jawaban para ibu atas dua pertanyaan ini dikumpulkan dan didiskusikan di antara mereka. Setelah jawaban para ibu dikumpulkan kemudian diambil kesimpulan lewat materi powerpoint yang telah disiapkan penyuluh. Materi power point dipakai sebagai pembahasan atas jawabanjawaban yang disampaikan ibu-ibu dalam diskusi tadi.

\section{HASIL DAN PEMBAHASAN HASIL}

Seperti dijelaskan pada bagian metode di atas bahwa penyuluhan dan diskusi dengan ibu-ibu di RW 018, Kelurahan Penjagalan, Kecamatan Penjaringan, Jakarta Utara berusaha mendiskusikan dua hal sebagai berikut:

1. Apa saja yang biasa dilakukan orang tua ketika anak-anak menghadapi masalah, seperti: penyalahgunaan obat terlarang atau narkoba, merokok, kecanduan internet, stres, terlibat dalam tindak kekerasan, pelecehan seksual, dan penyalahgunaan alkohol?

2. Bagaimana cara orangtua mengkomunikasikan tindakan pemecahan masalah yang sedang dihadapi seorang anak sehingga solusi yang ditawarkan tidak membuat anak-anak terluka?

Setelah dilakukan diskusi atas dua pertanyaan tadi, tampak hasilnya sebagai berikut: (1) Terhadap pertanyaan pertama didapat jawaban beragam dari para ibu bahwa hal-hal yang biasanya mereka lakukan ketika menghadapi anak bermasalah dalam hidupnya adalah sebagai berikut:

1. Menasihati.

2. Memberi bimbingan agama.

3. Marah-marahin anak.

4. Uang jajan dikurangi/tidak diberi sama sekali supaya tidak merokok atau ke warnet.

5. Lapor RW/pihak berwajib.

6. Diamin anak.

7. Menyuruh anak kerja.

8. Tanyain mengapa melakukan hal itu.

9. Lapor guru di sekolah

kedua, bagaimana mereka mengkomunikasikan tindakan pemecahan kalau anak terlanjur sudah menghadapi masalah. Para ibu tampak sedikit sulit menjelaskannya, tetapi ada beberapa jawaban menarik yang perlu dibahas lebih lanjut antara lain:

1. Terbuka mendengarkan anak.

2. Jangan cepat-cepat marah, tetapi tanya dulu apa masalahnya.

3. Menciptakan suasana supaya anak tidak merasa sedang diinterogasi.

4. Kasih sayang.

5. Jangan ngomong di belakangbelakang.

6. Panggil anaknya dan ajak diskusi

${ }^{11} \mathrm{lbid}$. 


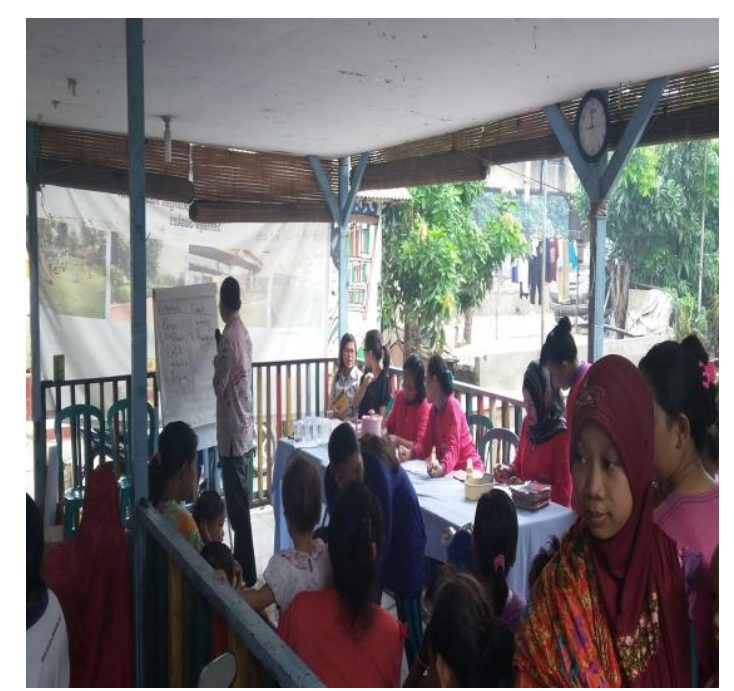

Gambar 1. Brainstorming Pendapat Ibu-Ibu Sumber: data primer peneliti, 2017

\section{PEMBAHASAN}

Pada bagian ini akan dibahas beberapa hal penting yang muncul dalam diskusi dan disesuaikan dengan materi yang telah disiapkan. Sebelum dibahas lebih lanjut, kita harus menegaskan posisi kita bahwa menjadi orangtua, tidak saja menjadi pendidik, pendamping, dan pemberi nafkah bagi kehidupan seorang anak, tetapi, yang jarang dilakukan orang tua adalah menjadi sahabat/teman bagi seorang anak. Menjadi teman berarti menjadi mereka yang mendengarkan; menjadi mereka yang terbuka; dan menjadi mereka yang jujur. Ketiga model komunikasi inilah yang akan dibahas dalam bagian-bagian berikut.

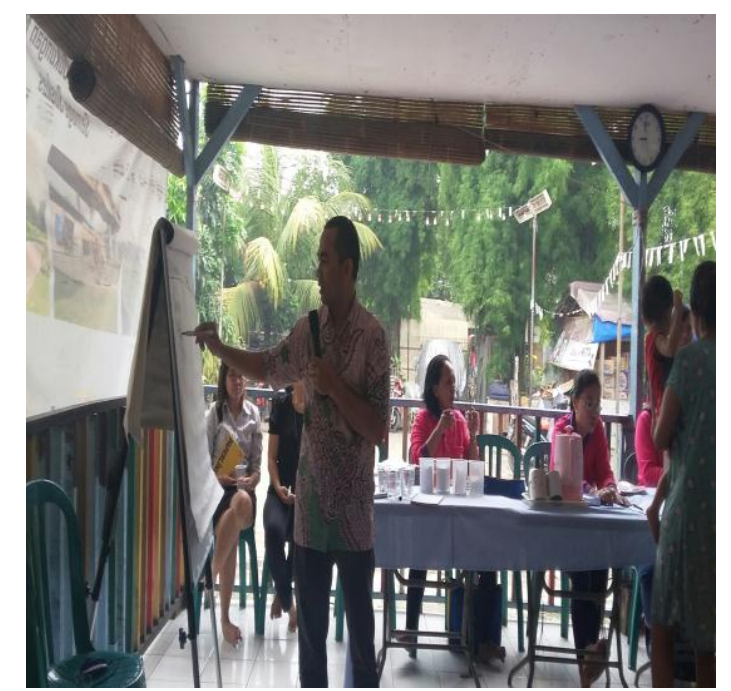

Gambar 2. Mencatat Hasil Diskusi

Sumber: data primer peneliti, 2017

\section{Komunikasi yang Mendengarkan}

Komunikasi yang mendengarkan adalah model komunikasi interpersonal orangtua dengan anak, atau suatu bentuk komunikasi yang terlibat, terutama dalam menjawabi berbagai kebutuhan psikologis anak. Segala bentuk pemberontakan anak dalam menuntut kebebasan adalah ekspresi dari kebutuhan tertentu yang mestinya segera dijawab para 
orang tua, dan mendengarkan apa yang mereka harapkan adalah salah satu cara untuk memahami mereka. ${ }^{12}$

Karena itu dengarkanlah keluh-kesah anak-anak anda karena mereka sedang membutuhkan anda sebagai seorang sahabat pendengar. Sahabat adalah mereka yang merasakan sesuatu sama seperti yang dirasakan remaja tersebut. Ukuran menjadi orang tua yang baik tidak saja karena sudah memenuhi semua kebutuhan hidup anak tetapi lebih dari itu orang tua yang mampu menjadi sahabat tempat mereka bisa berbagi beban hidup dan kerinduan untuk merencanakan masa depan yang baik.

Kita tahu bahwa komunikasi interpersonal dalam mendengarkan membutuhkan hubungan interpersonal yang baik pula. Kegagalan dalam berkomunikasi banyak terjadi karena isi pesan dipahami tetapi hubungan interpersonal tidak dijalin dengan baik. Komunikasi mendengarkan, dengan demikian, hanya efektif kalau disertai sikap konsentratif, pengalaman memainkan peran penting, disertai keterampilan mengelola suasana. Hasilnya anak mudah memahami apa yang diinginkan orang tua dari perilaku hidup mereka.

\section{Komunikasi yang Terbuka}

Effian Kadarusman ${ }^{13}$ dalam blog keluarga.com, menuliskan bahwa komunikasi yang baik selalu memiliki dua jalur, yaitu jalur penyampai pesan dan jalur pendengar pesan. Ketegangan dalam komunikasi terjadi ketika penyampai pesan memiliki pendapat sendiri atas suatu kenyataan dan cenderung menempatkan pendengar pesan sebagai yang selalu disalahkan.

Ketegangan ini bisa diatasi oleh model komunikasi yang terbuka, yaitu komunikasi yang memungkinkan penyampai pesan dan penerima pesan dapat memahami apa yang ingin dicapai dalam sebuah komunikasi yang sedang dijalankan. Orang tua sebagai penyampai pesan dan anak sebagai penerima

\footnotetext{
${ }^{12}$ Fensi, Fabianus., Op.cit. hal. 152

${ }^{13}$ Kadarusman, Effian. Komunikasi Terbuka. Diakses dari Blog Keluarga.com, pada tanggal 06 Juni 2017.
}

pesan menduduki posisi yang sama dalam pertukaran pesan komunikasi yang sedang mereka bangun.

Komunikasi yang terbuka dapat diterapkan kepada anak-anak kita. Komunikasi itu ditandai oleh ketegasan dalam mengungkapkan pikiran, gagasan, tujuan, dan bahkan perasaan tidak suka anda untuk kebaikan seorang anak dalam hidup yang sedang ia atau mereka jalani sekarang.

Bahkan, orang tua, tidak saja terbuka menyampaikan kekuatan, keunggulan, dan berbagai kemampuan yang dimilikinya, tetapi demi terbangunnya hubungan saling percaya dan kedekatan dengan anak, dia/mereka tidak perlu ragu-ragu mengungkapkan kelemahan anda di hadapan anak-anak. Hanya dengan cara demikian kepercayaan anak kepada orang tumbuh dengan baik. Komunikasi terbuka, tidak saja berguna untuk memperbaiki sikap sikap hidup anak, tetapi lebih dari itu anak merasa dihargai dan ditumbuhkan rasa percaya dirinya.

\section{Komunikasi yang Jujur}

Kejujuran adalah kualitas diri yang dimiliki orang tua dalam mendidik anak. Secara sederhana kejujuran dapat diartikan sebagai sikap untuk mengungkapkan sesuatu "benar" sebagai benar dan sesuatu "salah" sebagai salah. Sebaliknya disebut sebagai "bohong". Kejujuran adalah sikap terpuji dan anak akan mencontoh dari sikap jujur yang dimiliki orang tua tersebut. Orang tua tidak boleh mewariskan sikap bohong kepada anak, karena sikap itu akan dibudayakan anak dalam seluruh perjalanan hidupnya.

Berhadapan dengan anak-anak bermasalah komunikasi yang jujur adalah komunikasi yang menumbuhkan sikap menghargai diri anak. Kalau anak bersalah katakan apa salahnya dan bagaimana seharusnya dilakukan? Hal sebaliknya pun demikian, kalau benar, berhasil, atau mencapai kesuksesan tertentu, orang tua harus jujur memberi pujian dan apresiasi.

Harus dikatakan di sini bahwa kejujuran bukanlah bawaan kodrati tetapi ia dibentuk oleh proses belajar dan cara pembiasaan tertentu. Itu artinya kejujuran ditumbuhkan dari konteks sosial tertentu, 
yaitu lingkungan tempat di mana seorang anak bertumbuh dan berkembang. Logisnya, lingkungan jujur melahirkan pribadi anak yang jujur sebaliknya lingkungan penuh kebohongan melahirkan pribadi anak yang suka berbohong.

Dalam hal ini pola komunikasi orang tua yang jujur, seperti: mengatakan benar sebagai benar; salah sebagai salah; berani berjuang dan bertanggung jawab atas diri sendiri adalah sebagian dari contoh yang harus disampaikan orang tua kepada anakanak yang bermasalah dalam hidupnya. Kepada anak dapat disampaikan bahwa sikap jujur menguntungkan karena kita akan dipercaya; kita dicintai banyak orang; kalau mau bekerja mudah dapat pekerjaan; dan orang jujur dicintai Tuhan.

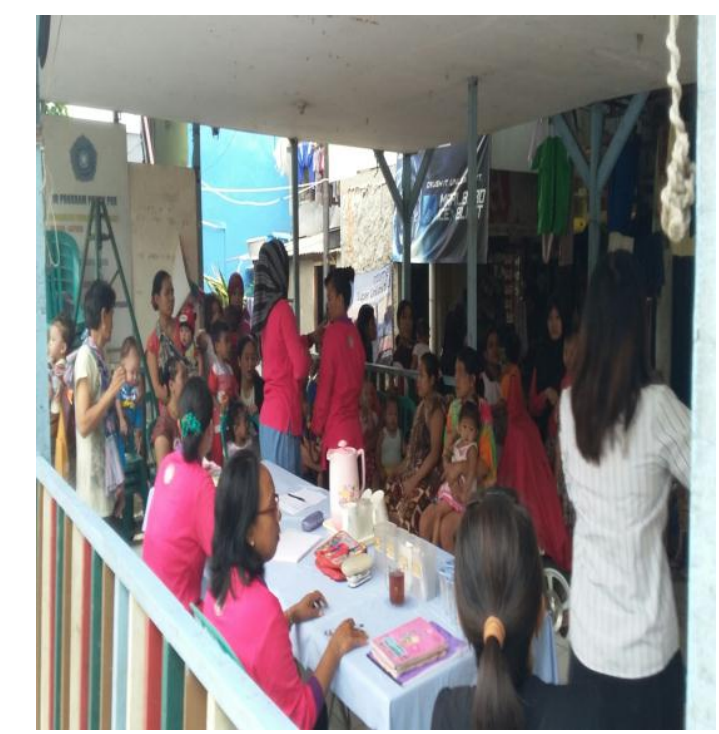
Gambar 3. Mendengarkan Kesimpulan Diskusi
Sumber: data primer peneliti, 2017

\section{SIMPULAN}

Tidak bisa disangkal bahwa sebagian besar masalah yang dihadapi anak bermasalah dalam lingkungan sosialnya terjadi karena lemahnya pengawasan dan ketegasan orang tua dalam memanfaatkan komunikasi interpersonal. Namun, kita juga mengakui bahwa orang tua tidak memiliki banyak referensi mengenai cara yang tepat untuk mengungkapkan model dan cara melakukan pengawasan dan menyampaikan ketegasan tersebut.

Kegiatan ini menyimpulkan bahwa ada banyak pola komunikasi interpersonal yang bisa dilakukan orang tua dalam menghadapi permasalahan anak-anak dewasa ini. Pola komunikasi yang biasa dilakukan orang tua, seperti: memberi nasihati; memberi bimbingan agama; marahmarahin anak; uang jajan dikurangi/tidak diberi sama sekali; lapor RW/pihak berwajib; didiamin; menyuruh anak kerja; atau melaporkan kepada guru; dan lain-lain, tidak bisa disalahkan atau ditolak sama sekali.

Semua pola komunikasi diberikan ini seharusnya diarahkan untuk menumbuhkan sikap percaya diri sekaligus menghargai diri seorang anak. Karena itu komunikasi yang mendengarkan; komunikasi yang terbuka; dan komunikasi yang jujur adalah alternatif model komunikasi yang empatik di mana anak merasa menjadi bagian dari proses penemuan dirinya dalam kehidupan sosial bersama orang tuanya.

Ketiga model komunikasi ini, selain sebagai cara terpenting untuk menemukan solusi atas masalah yang dihadapi anak, juga sebagai cara untuk melawan kecenderungan egoisme diri orang tua. Dengan pola-pola komunikasi ini orang tua mampu menyerap apa yang diharapkan anak-anak. Dan, dengan cara itu pula anak-anak merasa dimengerti dan dihargai oleh orang tua mereka. 


\section{DAFTAR PUSTAKA}

Budyatna, Muhammad \& Leila Mona Ganiem. (2012). Teori Komunikasi Antarpribadi. Jakarta: Prenada Media Group.

De Vito, Joseph. (2009). Komunikasi Antarmanusia. Jakarta: Profesional Books.

Fensi, Fabianus. (2016). "Mendengarkan sebagai Model komunikasi untuk Memahami Remaja" dalam Psibernetika, Vol. 9, No. 2.

Jo-Ann. (2012). "How to Become an Effective Communicator". Penton Media, Inc. Nov 26.

Kadarusman, Effian. "Komunikasi Terbuka". Diakses dari Blog Keluarga.com, pada tanggal 06 Juni 2017.

KPAI, 5 Juni 2013, http://www.kpai.go.id/tinjauan/10masalah-anak-yang-bikin-orang-tua- ketar-ketir/11/04/2017, diakses 11/04/2017, jam 16:09

KPAI, 5 Juni 2013, http://www.kpai.go.id/tinjauan/10masalah-anak-yang-bikin-orang-tuaketar-ketir/11/04/2017, diakses 11/04/2017, jam 16:00

Mulyana, Deddy. (2015). Komunikasi Suatu Pengantar (cetakan 19). Bandung: Rosdakarya.

Olifia, Hilda. "13 Kesalahan Komunikasi Orang Tua Terhadap Anak Yang Harus Segera Diubah", diakses dari http://www.rancahpost.co.id/2016025 1061/13-kesalahan-komunikasiorang-tua-terhadap-anak-yang-harussegera-diubah/, 18/04/2017, jam $14 ; 24$

Tubbs, Stewart L - Sylvia Moss. (2005). Human Communication (terjemahan Deddy Mulyana). Bandung: Rosdakarya. 